\title{
Sistem Among dalam Penerapan Nilai-nilai Luhur Pendidikan Karakter Ki Hadjar Dewantara
}

\author{
Fressi Apriliyanti ${ }^{1}$, Fattah Hanurawan ${ }^{2}$, Ahmad Yusuf Sobri ${ }^{3}$ \\ ${ }^{1}$ Pendidikan Anak Usia Dini-Universitas Negeri Malang \\ ${ }^{2}$ Pendidikan Psikologi-Universitas Negeri Malang \\ ${ }^{3}$ Administrasi Perkantoran-Universitas Negeri Malang
}

\section{INFO ARTIKEL}

\section{Riwayat Artikel:}

Diterima: 17-07-2019

Disetujui: 10-08-2020

\section{kata kunci:}

among system;

character building;

noble values:

sistem among;

pendidikan karakter;

nili-nilai luhur

\begin{abstract}
ABSTRAK
Abstract: The purpose of this study was to describe the wholeness of the Among System in the application of the noble values in the character education of Ki Hadjar Dewantara. The case study qualitative research data collected using in-depth interviews, observations and study documents. The data analysis technique in this study was thematic analysis and validated by source triangulation and method triangulation The results showed that the Among System demonstrated the application of the noble values of the education of Ki Hadjar Dewantara's characters in TK Taman Indria Malang City including the application of ing ngarso sung tulodho, ing madyo mangun karso, and Tut Wuri Handayani. The methods used in implementing of the Among System in TK Taman Indria contained methods of habit, exemplary, storytelling and conversing. The characters that appeared from the implementation of the Among System including politeness, responsibility, disciplines, orderly and accepting rules. Various strategies were used in the preservation of the noble values of the character education of $\mathrm{Ki}$ Hadjar Dewantara and were used in dealing with the obstacles in preserving the noble values of the education of Ki Hadjar Dewantara's characters in TK Taman Indria.

Abstrak: Tujuan penelitian ini adalah untuk mendeskripsikan secara menyeluruh mengenai Sistem Among dalam penerapan nilai-nilai luhur pendidikan karakter Ki Hadjar Dewantara. Rancangan penelitian yang digunakan adalah penelitian kualitatif studi kasus. Alat pengumpul data dalam penelitian ini adalah wawancara mendalam, observasi dan studi dokumen. Teknik analisis data dalam penelitian ini adalah tematik analisis. Derajat keterpercayaan dalam penelitian ini dicapai dengan menggunakan triangulasi sumber dan triangulasi metode. Hasil penelitian menunjukkan bahwa Sistem Among dalam penerapan nilai nilai luhur pendidikan karakter Ki Hadjar Dewantara di TK Taman Indria Kota Malang meliputi adanya Penerapan Ing Ngarso Sung Tulodho, Ing Madyo Mangun Karso, Tut Wuri Handayani. Metode dalam penerapan Sistem Among di TK Taman Indria antara lain metode pembiasaan, keteladanan, bercerita dan bercakap-cakap. Ditemukan berbagai strategi pelestarian nilai-nilai luhur pendidikan karakter Ki Hadjar Dewantara serta hambatan dalam pelestarian nilai-nilai luhur pendidikan karakter Ki Hadjar Dewantara di TK Taman Indria.
\end{abstract}

\author{
Alamat Korespondensi: \\ Fressi Apriliyanti \\ Pendidikan Anak Usia Dini \\ Universitas Negeri Malang \\ Jalan Semarang 5 Malang \\ E-mail: apriliyanti.fresy123@gmail.com
}

Pendidikan karakter bukanlah hal baru dalam dunia pendidikan (Huitt \& Vessels, 2002) dan bahkan telah berusia setua pendidikan itu sendiri (Lickona, 2012). Pendidikan karakter merupakan isu yang berkembang seiring dengan tumbuhnya kesadaran bahwa pendidikan karakter merupakan suatu hal yang sangat penting. Hal ini sejalan dengan tujuan pendidikan nasional yang menyatakan bahwa tujuan Pendidikan Nasional yaitu berkembangnya potensi peserta didik agar menhjadi manusia yang beriman dan bertakwa kepada Tuhan Yang Maha Esa, berakhlak mulia, sehat, berilmu, cakap, kreatif, mandiri dan menjadi warga negara yang demokratis serta bertanggung jawab (Undang-undang No 20 Tahun 2003 tentang Sistem Pendidikan Nasional, 2003). Pendidikan diharapkan tidak hanya mampu mencetak manusia Indonesia yang cerdas saja, namun juga diharapkan memiliki karakter yang mulia. Di lain pihak, kondisi yang terjadi dalam kehidupan berbangsa dan bernegara mencerminkan rendahnya nilai-nilai karakter. Berbagai permasalahan akibat rendahnya nilai-nilai karakter di Indonesia tercermin pada banyaknya persoalan, seperti tingginya angka korupsi di Indonesia, perilaku tawuran, bullying, dan kekerasan di sekolah. 
Lickona (2012) menegaskan bahwa hilangnya nilai nilai sosial merupakan peringkat pertama dari munculnya krisis di berbagai bidang, disusul kurang berfungsinya pendidikan dalam keluarga, pengabaian terhadap pendidikan karakter di sekolah dan contoh-contoh yang buruk yang diberikan oleh media. Dunia pendidikan memiliki sumbangsih besar dalam hal buruknya nilai karakter. Faktor faktor yang menyebabkan buruknya nilai karakter di sekolah menurut Akbar, Samawi, Arafik, \& Hidayah, (2015) antara lain pembelajaran di Indonesia ditengarai terlalu didominasi oleh kognitif, kurangnya keseimbangan dalam pengembangan pikiran dan hati, pembelajaran kurang berorientasi pada nilai-nilai yang diinternalisasikan, serta kurangnya penghargaan terhadap kemanusiaan manusia.

Berbagai penelitian telah memperlihatkan bahwa pendidikan anak usia dini yang berkualitas berpengaruh signifikan bagi perkembangan anak di masa yang akan datang dalam berbagai aspek kehidupan (Bakken, Brown, \& Downing, 2017; Samuelsson \& Kaga, 2008). Pendidikan karakter merupakan hal yang fundamental dan penting untuk dikembangkan, bahkan menjadi tujuan dari pendidikan itu sendiri (Lickona, 2012; Shields, 2011) sehingga perlu untuk diterapkan di sekolah sejak dini. Pendidikan karakter diyakini juga mampu memberikan dampak besar bagi anak di masa mendatang dimana menurut Bialik, Bogan, Fadel, \& Horvathova (2015) hasil riset menunjukkan kapasitas siswa di luar akademik memiliki peran penting dalam pencapaian dan bermanfaat di dunia kerja. Ketika pengetahuan dan keterampilan seseorang mungkin tidak dapat digunakan di berbagai bidang pekerjaan di masa yang akan datang, maka kualitas karakter dapat diaplikasikan dalam berbagai profesi. Bahkan pendidikan karakter sejak dini dapat dijadikan sebagai upaya preventif untuk membentuk generasi yang tangguh di masa yang akan datang (Chavez, 2014).

Masa usia dini merupakan periode optimum dalam pengembangan karakter (Berkowitz \& Hoppe, 2009) sehingga penanaman nilai karakter perlu diupayakan sejak usia dini. Manfaat pendidikan karakter pada anak usia dini diungkapkan oleh Lee (2013) bahwa pendidikan karakter yang diterapkan sejak usia dini dapat membangun sifat-sifat positif yang akan bermanfaat dalam lingkungannya, membangun identitas diri yang kuat serta rasa percaya diri. Nilai-nilai karakter yang perlu ditanamkan sejak dini, antara lain adalah kepercayaan, rasa hormat, tanggung jawab, keadilan, kepedulian dan kewarganegaraan (Chavez, 2014). Hasil riset yang dilakukan oleh Berkowitz \& Bier (2004) menunjukkan bahwa terdapat sepuluh nilai utama yang perlu ditanamkan sejak dini yaitu kontrol diri, empati, orientasi sosial, pemenuhan, harga diri, hati nurani, alasan moral, altruism, kejujuran, dan keterampilan sosial. Hasil penelitian Mei-Ju, Chen-Hsin, \& Pin-Chen (2014) menyatakan bahwa pendidikan karakter pada anak usia dini ditekankan pada beberapa dimensi, di antaranya kejujuran, kasih sayang, kesetiaan, menghormati, kepercayaan, dan tanggung jawab.

Studi yang dilakukan oleh Gopinathan (2006) memaparkan bahwa di berbagai negara baik Indonesia, Thailand, Singapura, dan Filipina menunjukkan pemahaman para pendidik di beberapa negara tersebut ternyata lebih mengenal teori-teori yang berasal dari Barat dari sisi filosofis, teori pendidikan, maupun sosiologi pendidikan. Ini artinya pemikiran-pemikiran pendidikan yang berasal dari warisan budaya lokal justru kurang dipahami oleh dunia pendidikan di berbagai negara tersebut. Perkembangan zaman yang begitu pesat ditandai dengan adanya globalisasi yang seringkali dimaknai sebagai the boarderless world, dunia tanpa tapal batas. Globalisasi yang ditandai dengan proses mendunianya sistem ekonomi, sosial, politik dan budaya.telah memberikan dampak yaitu terjadinya transfer, adaptasi dan pengembangan nilai, pengetahuan dan norma perilaku melintasi batas antar negara di berbagai belahan dunia (Blackwell \& Colmenar, 2000; Cheng, 2002). Berkaiitan dengan hal tersebut, walaupun arus globalisasi berdampak pada transfer yang melintasi batas antar negara, Gopinathan (2006) menyatakan bahwa dalam dunia pendidikan, nilai-nilai lokal sebetulnya lebih tepat untuk memecahkan berbagai permasalahan dibandingkan apabila mengambil nilai-nilai dari negara lain. Apabila merujuk pada pernyataan tersebut, maka semestinya bangsa Indonesia menjadikan nilai karakter yang berasal dari nilai-nilai luhur warisan bangsa sendiri sebagai solusi bagi berbagai permasalahan karakter di negeri ini, dalam hal ini adalah pendidikan karakter Ki Hadjar Dewantara.

Pendidikan karakter menurut Ki Hadjar Dewantara dinamakan budi pekerti. Dalam pandangan Ki Hadjar Dewantara, pendidikan karakter pada anak usia dini dilakukan dengan sistem among, yaitu dengan melalui asih, asah, asuh (Wangid, 2009). Sistem among sendiri berasal dari Bahasa Jawa yaitu mong atau momong, yang artinya mengasuh. Lebih lanjut dikatakan bahwa dalam sistem amog tersebut, seringkali dikaitkan dengan semboyan Tut Wuri Handayani: ing ngarso sung tulodho, ing madyo mangun karso, tut wuri handayani.

Ki Hadjar Dewantara mendirikan Perguruan Tamansiswa yang berkedudukan di Yogyakarta pada tanggal 3 Juli 1922. Di bawah naungan perguruan ini, terdapat jenjang pendidikan TK yang diberi nama Taman Indria, pada jenjang Sekolah Dasar dikenal sebagai Taman Muda, jenjang SMP disebut Taman Madya, Taman Dewasa untuk jenjang SMA dan Taman Guru/Sarjanawiyata untuk jenjang Perguruan Tinggi. TK Taman Indria merupakan salah satu bagian dari Perguruan Tamansiswa yang berlandaskan filosofi Ki Hadjar Dewantara. Di Kota Malang terdapat Perguruan Tamansiswa yang membawahi lembaga dari mulai Taman Indria, Taman Madya, Taman Muda, Taman Dewasa maupun Sarjanawiyata. Kontribusi Perguruan Tamansiswa dalam pendidikan anak usia dini ditunjukkan dengan adanya TK Taman Indria. Pada observasi awal diperoleh data yang menyatakan bahwa TK Taman Indria menerapkan sistem among sebagai ciri khas pergururn Tamansiswa. Hal inilah yang melandasi mengapa penelitian ini perlu dilakukan, yaitu untuk mengungkap pertama, bagaimana sistem among dalam penerapan nilai-nilai luhur pendidikan karakter Ki Hadjar Dewantara di TK Taman Indria, kedua faktor penghambat dalam melestarikan nilai-nilai luhur pendidikan karakter Ki Hadjar Dewantara di TK Taman Indria serta ketiga, bagaimana strategi yang dilakukan untuk melestarikan nilai-nilai luhur pendidikan karakter Ki Hadjar Dewantara. 


\section{METODE}

Penelitian ini menggunakan pendekatan kualitatif Penelitian ini bertujuan untuk mendeskripsikan secara menyeluruh dan mendalam kenyataan yang ada di lapangan, yaitu mengenai sistem among dalam penerapan nilai-nilai luhur pendidikan karakter Ki Hadjar Dewantara di TK Taman Indria berdasarkan pengumpulan data yang dilakukan, sebagaimana karakteristik penelitian kualitatif yaitu bersifat naturalistik/penelitian yang dilakukan pada setting alamiah, berfokus pada proses, bersifat induktif dan berfokus pada makna menurut perspektif partisipan (Bogdan \& Biklen, 1998; Merriam, 2009; Yin, 2011). Penelitian ini menggunakan rancangan penelitian studi kasus, yaitu suatu jenis penelitian kualitatif yang menggunakan beragam metode dan beragam sumber data untuk menjelaskan secara rinci dan mendalam tentang suatu unit analisis (Hanurawan, 2016).

Sumber data dalam penelitian ini antara lain sumber data insani dan sumber data non insani (Sobri, 2013). Sumber data insani terdiri dari Kepala Sekolah, guru, dan guru ekstrakurikuler di TK Taman Indria Kota Malang dan pengurus Perguruan Tamansiswa. Sumber data non insani terdiri dari literatur dan berbagai bahan tentang pendidikan karakter Ki Hadjar Dewantara, lingkungan sekolah TK Taman Indria Kota Malang, dokumen visi misi, profil sekolah, kurikulum, serta dokumen lainnya.

Data dalam penelitian ini diperoleh dari wawancara mendalam, observasi, dan analisa dokumen (Merriam, 1985). Data yang terkumpul dari wawancara, observasi, dan analisa dokumen kemudian dianalisis dengan menggunakan analisis tematik yang dilakukan dengan cara melakukan reduksi data dan strategi analisis dengan mengelompokkan, mengkategorikan, menyimpulkan dan merekonstruksi untuk menangkap konsep-konsep penting dalam kumpulan data (Ayres, 2008). Proses analisis tematik yang dilakukan dalam penelitian ini merujuk pada pendapat Braun \& Clarke (2006) yang menyatakan bahwa proses analisis tematik merupakan proses identifikasi, analisis, dan menyimpulan pola-pola tema yang ada dalam data.

Dalam penelitian ini, untuk memperoleh derajat keterpercayaan (trustworthiness) dilakukan dengan triangulasi sumber dan triangulasi metode. Proses triangulasi metode dalam penelitian ini dilakukan dengan melakukan pengujian dengan membandingkan data-data penelitian yang diperoleh dari berbagai metode (triangulasi metode), sedangkan triangulasi sumber dilakukan dengan melakukan pengujian dengan membandingkan data yang diperoleh dari berbagai sumber pada metode yang sama, yaitu metode wawancara (Patton, 1999).

\section{HASIL}

TK Taman Indria merupakan salah satu bagian dari Perguruan Tamansiswa cabang Malang. Didirikan pada tahun 1954, TK Taman Indria menjadi salah satu TK yang telah berumur lebih dari setengah abad. TK Taman Indria merupakan salah satu bagian dari sebuah perguruan yang memiliki filosofi dan karakteristik yang mencerminkan filosofi Ki Hadjar Dewantara, salah satu tokoh pendidikan yang merupakan Bapak Pendidikan Nasional Indonesia

Pendidikan karakter merupakan jiwa dalam pendidikan, demikian ungkapan dari Ki Hadjar Dewantara (Muthoifin \& Jinan, 2015). Sebagai sebuah lembaga yang berada di bawah naungan Perguruan Tamansiswa, pendidikan karakter di TK Taman Indria memiliki karakteristik atau ciri khas yang berbeda dengan yang diterapkan di tempat lain. Dari wawancara dengan berbagai sumber baik Kepala Sekolah, Ketua Yayasan Perguruan Tamansiswa dan guru diperoleh temuan bahwa ciri khas utama dari sebuah lembaga di bawah Perguruan Tamansiswa adalah Sistem Among. Lebih lanjut para informan mengatakan bahwa pendidikan karakter di TK Taman Indria dikenal dengan pendidikan budi pekerti, dimana sekolah menjadi tempat untuk bermain, dengan guru yang dinamakan sebagai pamong. Kata pamong menunjukkan bahwa sosok guru di TK Taman Indria tidak hanya sekedar memberi dan mentransfer ilmu, tetapi juga momong atau ngemong. Kata momong berasal dari bahasa Jawa yang berarti mengasuh.

Dalam sistem among tersebut, terdapat nilai Ing ngarso sung tulodho, yang bermakna di depan memberi contoh, artinya guru harus memberi contoh bagi anak-anaknya. Ing madyo mangun karso, yang artinya di tengah memberi semangat artinya guru dan tut wuri handayani yang artinya di belakang memberikan dorongan. Guru dalam sistem among memiliki peran untuk melakukan silih asah, silih asih dan silih asuh. Dalam sistem among, sekiranya tidak membahayakan murid, guru hanya perlu memantau. Jika membahayakan bagi anak, guru baru akan memberikan bantuan.

\section{Metode dalam Sistem Among di TK Taman Indria}

Hasil wawancara, observasi dan studi dokumen menunjukkan temuan bahwa proses pembelajaran dilakukan dengan melalui bermain. Setiap hari terdapat waktu khusus bagi anak untuk bermain baik permainan tradisional maupun permainan yang bersifat modern. Dengan bermain maka diharapkan anak bersekolah dengan rasa yang senang. Hasil observasi menunjukkan bahwa anak-anak bermain permainan dengan berbagai jenis permainan. Setiap pagi sesudah sholat dhuha berjama'ah, berbagai permainan dimainkan oleh seluruh anak di halaman sekolah. Berbagai permainan itu antara lain "sapu tangan", krupukan, gerak dan lagu yang dilakukan di halaman sekolah. Sesudah bermain di halaman anak bersama dengan guru melanjutkan pembelajaran di kelas yang dilakukan dengan suasana bermain. Kegiatan yang dilakukan dengan melalui bermain dilakukan di sentra. Contoh kegiatan yang dilakukan antara lain bermain puzzle dan mempresentasikan hasil karyanya, membuat maket kebun binatang, membuat teh manis dan mempresentasikan hasil karyanya, membuat kolase, melipat baju, menalikan sepatu. 
Berdasarkan hasil wawancara yang dilanjutkan dengan observasi selama empat bulan diperoleh temuan yang menyatakan bahwa penanaman budi pekerti pada anak di TK Taman Indria dilakukan dengan pembiasaan. Anak dibiasakan untuk melakukan perbuatan perbuatan baik secara terus menerus dan dibiasakan setiap hari. Setiap pagi anak dibiasakan memberi salam kepada orang tua atau orang yang mengantar, sesudah itu anak memberi salam kepada guru yang menyambut di sebelah gerbang sekolah, pembiasaan untuk melepas dan meletakkan sepatu di tempatnya, pembiasaan berdoa sebelum dan sesudah berbagai aktivitas, membuang sampah di tempatnya, sholat dhuha berjamaah, berbaris, senam pagi.

Karakter yang tampak dari pembiasaan-pembiasaan tersebut adalah sopan santun, tanggung jawab, disiplin, tertib, dan mengikuti aturan. Karakter sopan tampak pada saat anak mencium dan memberi salam baik kepada orang tua yang mengantar maupun pada guru, serta tampak dalam pembiasaaan untuk berjalan dengan mengatakan "permisi" jika lewat di depan orang yang lebih tua dan membungkukkan badan. Karakter tanggung jawab tampak ketika anak terbiasa melipat sendiri mukena atau sarung yang telah digunakan, membuang sampah di tempat sampah dan meletakkan sepatu di tempatnya. Hasil observasi menunjukkan karakter disiplin tampak pada saat anak datang ke sekolah tepat waktu, melakukan kegiatan sesuai dengan waktu yang telah ditentukan. Karakter tertib tampak pada saat anak berdoa bersama, mendengarkan guru berbicara dan melakukan sholat berjama'ah dengan tertib.

Berdasarkan observasi, diperoleh temuan mengenai metode keteladanan yang ditunjukkan oleh guru dan orang dewasa di lingkungan sekolah terutama dalam hal menepati waktu, memberi dan membalas salam sehingga menimbulkan karakter disiplin dan sopan santun pada anak didik. Hasil wawancara, observasi kegiatan pembelajaran maupun studi dokumen perencanaan pembelajaran menunjukkan bahwa penanaman budi pekerti luhur lainnya adalah melalui cerita, dialog dan bercakap-cakap. Melalui cerita, pesan yang diberikan oleh guru dapat menancap kuat dalam ingatan anak. Ketika guru memberi nasehat melalui cerita, misalnya untuk menanamkan karakter berbagi, anak mau berbagi di sekolah dan dari hasil wawancara dengan wali murid, anak menunjukkan sikap berbagi di rumah.

\section{Hambatan Dalam Penanaman dan Pelestarian Nilai-Nilai Luhur Pendidikan Karakter Ki Hadjar Dewantara}

Terdapat beberapa hambatan dan kendala dalam penerapan nilai-nilai luhur pendidikan karakter di TK Taman Indria. Pertama, faktor perkembangan zaman dimana terjadi perkembangan ilmu pengetahuan dan teknologi menjadi faktor penghambat pelestarian nilai-nilai luhur pendidikan karakter. Hal ini berkaitan dengan pengaruhnya terhadap masyarakat. Kedua, adanya tuntutan orangtua tentang kemampuan akademik sebagai ukuran keberhasilan, misalnya ukuran anak yang pintar adalah dari kemampuan membaca, menulis dan berhitung. Ketiga, sumber daya manusia atau dari individu guru itu sendiri. Baik dari tingkat pemahaman tentang ketamansiswaan maupun berkaitan dengan karakter dan kepribadian guru.

Hambatan keempat berasal dari anak maupun orangtua, adakalanya orangtua tidak merasa membutuhkan pendidikan karakter, namun hanya membutuhkan anak menjadi pintar. Jika orangtua di rumah tidak memberikan dukungan terhadap apa yang dilakukan oleh sekolah, tanpa sinergi antara orangtua dan sekolah maka penanaman nilai karakter tidak akan berjalan optimal. Contohnya ketika di sekolah diajarkan santun, mandiri, anak dibiasakan memakai sendiri sepatunya, namun di rumah dipakaikan oleh orang lain

\section{Strategi Dalam Melestarikan Nilai-Nilai Luhur Pendidikan Karakter Ki Hadjar Dewantara di TK Taman Indria}

TK Taman Indria sebagai bagian dari Perguaruan Tamansiswa telah berdiri sejak tahun 1954. Hasil wawancara dan observasi menunjukkan hasil bahwa tidak mudah untuk mempertahankan eksistensi nilai-nilai luhur pendidikan karakter Ki Hadjar Dewantara. Berbagai upaya dilakukan untuk dapat melestarikan nilai-nilai luhur tersebut. Strategi yang dilakukan antara lain, pertama dengan melakukan pemahaman dan pendidikan tentang ketamansiswaan, baik pembinaan berupa kunjungan dari Pergururan Tamansiswa Pusat ke cabang maupun pembinaan yang sifatnya rutin dilakukan, yaitu berupa Pertemuan Rabu Wage dengan membahas Ketamansiswaan. Jika di Perguruan Tamansiswa Pusat yaitu di Yogyakarta pertemuan dilakukan di hari Sloso Kliwon maka di Kota Malang dilakukan di hari Rabu Wage untuk menyesuaikan dengan budaya di kota Malang.

Strategi berikutnya adalah mengadakan kunjungan ke TK Taman Indria Pawiyatan Yogyakarta sebagai pusat dari Perguruan Tamansiswa. Tujuan kunjungan adalah supaya para guru Taman Indria Kota Malang dapat mengetahui gambaran penerapan nilai-nilai Ki Hadjar Dewantara di Tamansiswa pusat. Strategi ketiga adalah dengan melakukan sosialisasi nilai-nilai karakter baik kepada guru maupun kepada wali murid. Sosialisasi kepada guru dilakukan dengan melalui pertemuan sedang sosialisasi kepada wali murid dilakukan setahun dua kali yaitu pada awal tahun ajaran baru dan pada saat penerimaan rapor. Tujuan dari kegiatan sosialisasi ini adalah untuk mengenalkan dan memberikan pemahaman kepada guru dan wali murid untuk dapat memahami nilai-nilai luhur pendidikan karakter Ki Hadjar Dewantara, namun hal ini belum berjalan dengan hasil optimal. Hal ini dapat dilihat dari hasil wawancara baik kepada guru maupun wali murid yang kurang mengetahui nilai-nilai karakter yang ditanamkan di TK Taman Indria. Upaya pelestarian nilai luhur pendidikan karakter Ki Hadjar Dewantara juga dilakukan dengan cara menyediakan wahana bagi anak bermain dolanan tradisional terutama englek. 


\section{PEMBAHASAN}

Pendidikan karakter menurut Ki Hadjar Dewantara dinamakan sebagai pendidikan budi pekerti (Dewantara, 2013; Tamansiswa, 2013) yang diartikan sebagai bulatnya jiwa manusia, sebagai jiwa yang" berasas hukum kebatinan". Pendidikan karakter merupakan jiwa dari pendidikan menurut Ki Hadjar Dewantara (Muthoifin \& Jinan, 2015). Hal tersebut menunjukkan bahwa pendidikan karakter menjadi suatu prioritas dalam suatu lembaga yang berada di bawah naungan Perguruan Tamansiswa. Hal ini sejalan dengan pernyataan Berkowitz \& Hoppe (2009) bahwa keberhasilan penerapan pendidikan karakter yang dipengaruhi oleh banyak faktor, dimana faktor pertama dan yang menjadi dasar keberhasilan pendidikan karakter di suatu sekolah adalah bagaimana suatu lembaga menjadikan karakter sebagai sebuah prioritas. Pernyataan tersebut sejalan dengan Elbott \& Fulton (2008) yang menyatakan bahwa dalam membangun suatu budaya sekolah lembaga perlu menjadikan pendidikan karakter sebagai pusat misi dan prioritas kelembagaan.

Penerapan pendidikan karakter di TK Taman Indria didasarkan pada sistem among yang didalamnya terdapat falsafah ing ngarso sung tulodho (di depan memberikan contoh), ing madyo mangun karso (di tengah membangun motivasi), tut wuri handayani (di belakang memberikan dorongan). Guru memiliki peran penting dalam pendidikan karakter yaitu dengan prinsip Ing ngarso sung tulodho hal ini sesuai dengan hasil penelitian dari Berkowitz \& Bier (2016) yang menyatakan bahwa perlunya teladan dari semua orang dewasa di sekolah untuk menjadi model dan teladan bagi penerapan nilai karakter pada anak. Dalam hal "Ing madyo mangun karso "(ditengah memberikan motivasi), sesuai dengan pernyataan (Lickona, 2012) bahwa guru dalam pendidikan karakter merupakan mentor yang memberikan instruksi dan bimbingan, berdiskusi di kelas, bercerita, memberikan motivasi personal dan memberikan umpan balik yang bersifat korektif ketika terdapat siswa yang menyakiti diri sendiri maupun orang lain.

Guru dalam perannya tut wuri handayani yang artinya di belakang memberikan dorongan memiliki kesesuaian dengan pendapat Lickona (2012) yang menyatakan bahwa guru dalam pendidikan karakter menjadi seorang penyayang yang efektif, menghormati murid-muridnya, membantu anak untuk meraih sukses di sekolah, membangun kepercayaan diri anak didik. TK Taman Indria menjadikan sekolah menjadi tempat untuk bermain, dengan guru yang dinamakan sebagai pamong, sehingga proses pembelajaran dilakukan dengan melalui bermain. Penggunaan kata pamong bagi guru menunjukkan bahwa sosok guru di TK Taman Indria tidak hanya sekedar memberi dan mentransfer ilmu (transfer of knowledge), tetapi juga momong atau ngemong. Kata momong berasal dari bahasa Jawa yang berarti mengasuh.

Proses pembelajaran yang dilakukan dengan bermain merupakan jiwa dari pendidikan pada anak usia dini sehingga berbagai permainan anak kemudian dijadikan kultur di sekolah (Dewantara, 2013). Menurut Ki Hadjar Dewantara, permainan menduduki peran yang sangat penting dalam Pendidikan Anak Usia Dini, bahkan latihan keolahragaan dan permainan kanakkanak erat hubungannya dengan bertumbuhnya budi pekerti. Hal tersebut sejalan dengan pendapat Trinick \& Pohio (2018) yang menyatakan bahwa inti dari pembelajaran anak-anak adalah dengan bermain yang dilakukan secara alami, otentik, dan kuat oleh anak-anak untuk belajar. Melalui bermain, anak-anak memperoleh keterampilan sosial dan emosional yang penting untuk perkembangan psikologis yang sehat. Anak-anak menciptakan situasi imajiner, mendefinisikan peran dengan aturan implisit, dan menggunakan bahasa dan pemikiran simbolis untuk mengekspresikan ide dalam berbagai cara.

Pernyataan di atas dikuatkan oleh pendapat Sandberg \& Ärlemalm-hagsér (2011) yang menyatakan bahwa pembelajaran yang menyenangkan dan dilakukan dengan bermain dalam pendidikan anak usia dini dapat meletakkan dasar bagi lebih banyak anak untuk berhasil di sekolah. Anak-anak di ruang kelas yang menyenangkan penuh dengan bermain memperoleh keterampilan melek huruf dan konsep tingkat yang lebih tinggi dan mengembangkan keterampilan bahasa dan sosial yang lebih maju. Mereka juga belajar mengatur perilaku fisik dan kognitif mereka. Metode pembiasaan yang dilakukan di TK Taman Indria antara lain penyambutan tiap pagi, sholat dhuha berjamaah, berbaris, senam pagi, berdoa sebelum dan sesudah berbagai kegiatan. Dari pembiasaan tersebut karakter yang tampak adalah disiplin dan tertib, mengikuti aturan dan menghargai waktu. Secara umum, nilai karakter Ki Hadjar Dewantara yang dikembangkan pada anak adalah nilai karakter sopan santun. Implementasi sehari-hari melalui pembiasaan secara terus menerus maka nilai karakter yang dikemukanan yaitu nilai ketertiban, kedisiplinan, kejujuran, tanggung jawab, dan sopan santun.

Pembentukan karakter melalui pembiasaan sejalan dengan hasil penelitian Sobri (2013) yang menyatakan bahwa pembiasaan rutin adalah kegiatan yang dilakukan secara regular di sekolah yang bertujuan untuk membisakan siswa untuk mengerjakan sesuatu dengan baik. Sejalan dengan hal tersebut, Narvaez \& Lapsley (2008) menyatakan bahwa pembiasaan (habituation) merupakan suatu perilaku yang dilakukan secara berulang dangan serangkaian prosedur yang dilakukan dengan cara tertentu. Terdapat sumber klasik mengenai pembiasaan, yitu berasal dari Buku II Etika Nichomachean (NE) Aristoteles mengenai sifat dan definisi kebajikan. Aristoteles berpendapat bahwa kebajikan moral bukanlah bagian alami dari anugerah manusia, tetapi harus terjadi sebagai hasil dari pembiasaan.

Selain metode pembiasaan, metode keteladanan ditunjukkan oleh guru dan orang dewasa di lingkungan sekolah terutama dalam hal menepati waktu, memberi dan membalas salam sehingga menumbuhkan karakter disiplin dan sopan santun pada anak didik. Hal ini sejalan dengan peran guru dalam falsafah Ing ngarso sung tuladha (di depan memberikan teladan) yang dikemukakan oleh (Dewantara, 2013). Dengan memberikan teladan maka anak mendapat contoh dari orang dewasa di sekitar terutama di sekolah adalah dari guru. 


\section{Hambatan Dalam Pelestarian Nilai-Nilai Luhur Pendidikan Karakter Ki Hadjar Dewantara}

Berkenaan dengan faktor perkembangan zaman berupa perkembangan ilmu pengetahuan dan teknologi, sebagaimana pernyataan dari Allen (2003) bahwa kehadiran teknologi mambawa dampak yang signifikan bagi pendidikan maupun kehidupan masyarakat. Hasil penelitian menunjukkan bahwa guru justru perlu memanfaatkan ketertarikan murid terhadap penguasaan teknologi, dan tidak merasa terancam oleh hal tersebut.

Faktor individu guru baik berupa sikap pribadi maupun yang berkaitan dengan pemahaman tentang nilai-nilai luhur Ki Hadjar Dewantara. Hanya dua orang guru yang memiliki dasar pendidikan Tamansiswa sedangkan lainnya berasal dari luar Tamansisiwa. Hal ini menjadi faktor penghambat bagi pelestarian nilai-nilai luhur pendidikan karakter Ki Hadjar Dewantara. Seharusnya, guru memiliki pemahaman yang mencukupi dalam memahami nilai-nilai luhur pendidikanan karkater Ki Hadjar dewantara. Hal ini sejalan dengan penelitian Berkowitz \& Bier (2016) yang menyatakan bahwa perlunya peningkatan kompetensi guru dalam memahami bagaimana penanaman nilai karakter secara efektif.

Orangtua tidak merasa membutuhkan pendidikan karakter, namun hanya membutuhkan anak menjadi pintar, sehingga pendidikan karakter dipandang bukan motivasi yang utama dalam pendidikan. Sebagaimana hasil penelitian (Lee, 2013) yang menyatakan bahwa konteks pendidikan saat ini didominasi oleh kompetisi, standar akademik berupa nilai ujian sebagai penetu dari keberhasilan akademik anak.

\section{Strategi untuk Melestarikan Nilai-Nilai Luhur Pendidikan Karakter Ki Hadjar Dewantara}

Pentingnya pemahaman guru mengenai nilai-nilai karakter diungkapkan oleh Lickona (1997) menyatakan bahwa guru harus memiliki pemahaman yang mendalam mengenai nilai-nilai yang akan diterapkan dalam pendidikan karakter. Untuk dapat memberikan pemahaman mengenai nilai-nilai luhur pendidikan karakter Ki HadjarDewantara maka dilaksanakan pembinaan yang berupa kunjungan baik dari Perguruan Tamansiswa pusat maupun pembinaan yang bersifat rutin. Adanya pertemuan Rabu Wage sebagai sarana untuk memberikan pemahaman kepada para guru di lingkungan Tamansiswa terutama mengenai nilai luhur pendidikan karakter KI Hadjar Dewantara. Hal ini sejalan dengan pendapat dari Berkowitz \& Bier (2016) yang menyatakan bahwa sekolah perlu mengalokasikan sumberdaya untuk peningkatan kompetensi para guru dalam memahami penerapan pendidikan karakter supaya berjalan efektif.

Upaya lain dalam melestarikan nilai-nilai luhur Ki Hadjar Dewantara adalah dengan melakukan kunjungan studi banding ke TK Taman Indria Pawiyatan Yogyakarta. Kunjungan ini dimaksudkan untuk memberikan pemahaman tentang bagaimana pelaksanaan pembelajaran di TK Taman Indria Pawiyatan sebagi pusat dari Perguruan Tamansiswa di Indonesia. Hal ini senada dengan hasil penelitian dari Sobri (2013) yang menyatakan bahwa untuk memperkaya pengalaman guru dalam pengembangan dan inovasi pembelajaran, sekolah memprogram kegiatan studi banding atau kunjungan antar sekolah.

\section{SIMPULAN}

Sistem among merupakan ciri khas dalam pendidikan karakter di TK Taman Indria yaitu berupa, ing ngarso sung tulodho, ing madyo mangun karso, tut wuri handayani. Guru dalam sistem among memiliki peran untuk melakukan silih asah, silih asih dan silih asuh. Metode yang digunakan adalah pembiasaan, bercerita, dialog dan bercakap-cakap. Metode pembiasaan menghasilkan karakter yang tampak pada anak antara lain sopan santun, tanggung jawab, disiplin, tertib, dan men gikuti aturan . Metode cerita memberikan dampak anak mau berbagi. Metode keteladanan yang ditunjukkan oleh guru dan tenaga kependidikan di TK Taman Indria adalah menepati waktu, memberi dan membalas salam sehingga dapat menjadikan anak memiliki karakter disiplin dan sopan santun.

Faktor penghambat pelestarian nilai-nilai luhur pendidikan karakter Ki Hadjar Dewantara adalah pertama, faktor perkembangan zaman berupa perkembangan ilmu pengetahuan dan teknologi; kedua, tuntutan orangtua tentang kemampuan akademik sebagai ukuran keberhasilan; ketiga, faktor individu guru baik berupa sikap pribadi maupun yang berkaitan dengan pemahaman tentang nilai-nilai luhur Ki Hadjar Dewantara; dan keempat, adanya anggapan orangtua bahwa pendidikan karakter bukan hal yang penting

Strategi yang dilakukan oleh TK Taman Indria untuk melestarikan nilai-nilai luhur pendidikan karakter Ki Hadjar Dewantara, meliputi (1) melalui program pembinaan berupa kunjungan yang dilakukan Pergutruan Tamansiswa Pusat maupun cabang, (2) adanya pertemuan Rabu Wage sebagai sarana untuk memberikan pemahaman kepada para guru di lingkungan Tamansiswa terutama mengenai nilai luhur pendidikan karakter Ki Hadjar Dewantara, (3) mengadakan sosialisasi mengenai nilai-nilai luhur pendidikan karakter Ki Hadjar Dewantara menyediakan tempat bagi anak untuk melakukan permainan tradisional berupa paving halaman yang digambar dengan pola permainan tradisional engklek, (4) mengenalkan permainan tradisional walaupun belum dilakukan secara optimal. Sebagai bagian dari khasanah ilmu pengetahuan yang bersumber pada jati diri bangsa, sistem among perlu untuk dikaji secara lebih mendalam berupa pengembangan model pembelajaran berbasis sistem among untuk menjadi rujukan bagi pelaksanaan sistem among dalam pendidikan. 


\section{DAFTAR RUJUKAN}

Akbar, S., Samawi, A., Arafik, M., \& Hidayah, L. (2015). Pendidikan Karakter: Best Practices. Malang: Universitas Negeri Malang Press.

Allen, D. W. (2003). The Effects of Technology on Educational Theory and Practice. Computers in the Schools: Interdisciplinary Journal of Practice, Theory, and Applied Research, 20(1-2), 49-57.

Ayres, L. (2008). Thematic Coding and Analysis. In L. M. Given (Ed.), The SAGE Encyclopedia of Qualitative Research (p. 1063). Thousand Oaks, California: SAGE Publication.

Bakken, L., Brown, N., \& Downing, B. (2017). Early Childhood Education: The Long-Term Benefits. Journal of Research in Childhood Education, 31(2), 255-269. https://doi.org/10.1080/02568543.2016.1273285

Berkowitz, M. W., \& Bier, M. (2004). Research-Based Character Education. The ANNALS of The American Academy of Political Science, 591(1), 72-85.

Berkowitz, M. W., \& Bier, M. C. (2016). Effective Features and Practices that Support Character Development Center for Character and Citizenship, University of Missouri-St. Louis Brian McCauley Wasatch Academy (Utah ). 1-39.

Berkowitz, M. W., \& Hoppe, M. A. (2009). Character education and gifted children. High Ability Studies, 20 (2), $131-142$. https://doi.org/10.1080/13598130903358493

Bialik, M., Bogan, M., Fadel, C., \& Horvathova, M. (2015). Character education for the 21 st century. (February). Retrieved from http://curriculumredesign.org/wp-content/uploads/CCR-CharacterEducation_FINAL_27Feb2015.pdf

Blackwell, A. G., \& Colmenar, J. D. R. (2000). Community Building from Local Wisdom to Public Policy. Public Health Reports, 115, 161-166.

Bogdan, R. C., \& Biklen, S. K. (1998). Qualitative Research for Education: An Introduction to Theory and Methods (3rd ed.). New York: Allyn \& Bacon.

Braun, V., \& Clarke, V. (2006). Using Thematic Analysis in Psychology. Qualitative Research in Psychology, 3(2), $77-101$.

Chavez, B. (2014). Character Education as Prevention: A Focused Review of The Literature. Wyoming Survey \& Analysis Center, (January), 1-20.

Cheng, Y. C. (2002). Fostering Local Knowledge and Wisdom in Globalized Education : Multiple Theories. The 8th International Conference on "Globalization and Localization Enmeshed: Searching for a Balance in Education", 1-36.

Dewantara, K. H. (2013). Bagian I: Pendidikan. Yogyakarta: UST Press \& Majelis Luhur Persatuan Tamansiswa.

Elbott, C. E., \& Fulton, D. (2008). Building an Intentional School Culture. In Building an Intentional School Culture (p. 314).

Gopinathan, S. (2006). Challenging the paradigm: Notes on developing an indigenized teacher education curriculum. Improving Schools, 9(3), 261-272. https://doi.org/10.1177/1365480206069020

Hanurawan, F. (2016). Metode Penelitian Kualitatif (1st ed.). Jakarta: Rajawali Pers.

Huitt, W. G., \& Vessels, G. G. (2002). Character Education. In J. Guthrie (Ed.), Encyclopedia of Education (2nd Editio, pp. 259-263). New York: Macmillan.

Lee, G. (2013). Re-emphasizing Character Education in Early Childhood Programs: Korean Children's Experiences. Childhood Education, 89(5), 315-322. https://doi.org/10.1080/00094056.2013.830907

Lickona, T. (1997). The Teacher's Role in Character Education. Journal of Education, 179(2), 63-80.

Lickona, T. (2012). Mendidik untuk Membentuk Karakter: Bagaimana Sekolah dapat Memberikan Pendidikan tentang Sikap Hormat dan Bertanggungjawab. Jakarta: Bumi Aksara.

Mei-Ju, C., Chen-Hsin, Y., \& Pin-Chen, H. (2014). The Beauty of Character Education on Preschool Children's Parent-child Relationship. Procedia - Social and Behavioral Sciences, 143, 527-533. https://doi.org/10.1016/j.sbspro.2014.07.431

Merriam, S. B. (1985). The Case Study in Educational Research: A Review of Selected Literature. The Journal of Educational Thought, 19(3), 204-217.

Merriam, S. B. (2009). Qualitative Research: A Guide to Design and Implementation (Revised and Expanded from Qualitative Research and Case Study Application in Education. San Fransisco: Jossey-Bass.

Muthoifin, \& Jinan, M. (2015). Pendidikan Karakter Ki Hadjar Dewantara: Studi Kritis Pemikiran Karakter dan Budi Pekerti dalam Tinjauan Islam. Profetika, Jurnal Studi Islam, 16(2), 167-180.

Narvaez, D., \& Lapsley, D. K. (2008). Teaching Moral Character : Two Alternatives for Teacher Education. The Teacher Educator, 43(2), 156-172. https://doi.org/10.1080/08878730701838983

Patton, M. Q. (1999). Enhancing The Quality and Credibility of Qualitative Analysis. Health Services Research, 34(5 Pt 2), 1189-1208.

Samuelsson, I. P., \& Kaga, Y. (2008). Early Childhood Education for a Sustainable Society. In UNESCO. Retrieved from http://unesdoc.unesco.org/images/0015/001593/159355E.pdf

Sandberg, A., \& Ärlemalm-hagsér, E. (2011). The Swedish National Curriculum: Play and Learning with Fundamental Values in Focus. Australaysian Early Childhood Education, 36(1), 44-50. https://doi.org/10.1177/183693911103600108

Shields, D. L. (2011). Character as the Aim of Education. Kappan, 92(8), 48-53. https://doi.org/10.17715/jme.2007.02.18.2.143

Sobri, A. Y. (2013). Pembinaan Profesionalisme Guru dalam Meningkatkan Kualitas Pembelajaran. Jurnal Sekolah Dasar, 24(1), 9-20.

Tamansiswa, M. L. P. (2013). Kurikulum Pendidikan Tamansiswa. Yogyakarta: Majelis Luhur Persatuan Tamansiswa. 
1055 Jurnal Pendidikan, Vol. 5, No. 8, Bln Agustus, Thn 2020, Hal 1048-1055

Trinick, R., \& Pohio, L. (2018). The “ Serious Business” of Musical Play in the New Zealand Early Childhood Curriculum. Music Education Journal, 20-24. https://doi.org/10.1177/0027432118767734

Undang-undang No 20 Tahun 2003 tentang Sistem Pendidikan Nasional. (2003). Jakarta: Visimedia.

Wangid, M. N. (2009). Sistem Among pada Masa Kini: Kajian Konsep dan Praktik Pendidikan. Jurnal Kependidikan, 39(2), $129-140$.

Yin, R. K. (2011). Qualitative Research from Start to Finish. New York: The Guilford Press. 